\title{
Atrioventricular canal defect and genetic syndromes: The unifying role
}

\section{of Sonic Hedgehog}

M.C. Digilio, ${ }^{1}$ F. Pugnaloni, ${ }^{2}$ A. De Luca, ${ }^{3}$ G. Calcagni, ${ }^{1}$ A. Baban, ${ }^{1}$ M.L. Dentici, ${ }^{1}$ P. Versacci, ${ }^{2}$ B. Dallapiccola, ${ }^{1}$ M. Tartaglia, ${ }^{1}$ B. Marino $^{2}$

(1)

\author{
B. Dallapiccola, ${ }^{1}$. Tartaglia, ${ }^{1}$ B. Marino
}

${ }^{1}$ Medical Genetics, Pediatric Cardiology, Genetics and Rare Diseases Research Division, Bambino Gesù Pediatric Hospital, Rome, Italy

\author{
${ }^{2}$ Department of Pediatrics, Sapienza University, Rome, Italy \\ ${ }^{3}$ Laboratory of Molecular Biology, CSS-Mendel Institute, Rome, Italy
}

Short informative title: Atrioventricular canal defect, syndromes and Hedgehog pathway

Short title: Atrioventricular canal defect and Hedgehog

$(3$

Conflict of interest

The authors have no conflicts of interest to declare

Corresponding author: M.Cristina Digilio, MD, Medical Genetics, Bambino Gesù Paediatric

Hospital, IRCCS, Piazza S. Onofrio 4, 00165 Rome, Italy. Tel: +39-06-68592743; E-mail:

digilio@opbg.net

The atrioventricular canal defect (AVCD) is a congenital heart defect (CHD) frequently associated with

This article has been accepted for publication and undergone full peer review but has not been through the copyediting, typesetting, pagination and proofreading process, which may lead to differences between this version and the Version of Record. Please cite this article as doi: 10.1111/cge.13375 
extracardiac anomalies (75\%). Previous observations from a personal series of patients with AVCD and "polydactyly syndromes" demonstrated that the distinct morphology and combination of AVCD features in some of these syndromes is reminiscent of the cardiac phenotype found in heterotaxy, a malformation complex previously associated with functional cilia abnormalities and aberrant Hedgehog (Hh) signaling. Hh signaling coordinates multiple aspects of left-right lateralization and cardiovascular growth. Being active at the venous pole of the Secondary Heart Field (SHF), is essential for normal development of dorsal-mesenchymal protrusion and AVCD formation and septation. Experimental data show that perturbations of different components of the Hh pathway can lead to developmental errors presenting with partially overlapping manifestations and AVCD as a common denominator. We review the potential role of Hh signaling in the pathogenesis of AVCD in different genetic disorders. AVCD can be viewed as part of a "developmental field", according to the concept that malformations can be $\int d$ due to defects in signal transduction cascades or pathways, as morphogenetic units which may be altereted by Mendelian mutations, aneuploidies, environmental causes.

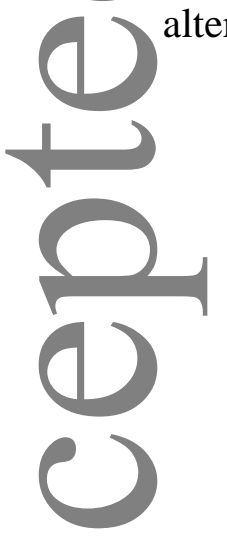

Key words: atrioventricular septal defect - heterotaxy - sonic hedgehog - cilium - secondary heart field - syndrome

\section{INTRODUCTION}

This article reviews the potential role of Hedgehog signaling in the pathogenesis of atrioventricular 
canal defect (AVCD) in different genetic disorders, based on recent experimental findings which show that dorsal mesocardial protrusion (DMP) development requires cilia-based Hedgehog (Hh) signaling, and that cilia are structurally present in the secondary heart field (SHF). ${ }^{1,2}$ Previous observations from a personal series of patients with AVCD and "polydactyly syndromes” demonstrated that the distinct morphology and combination of AVCD features in some of these syndromes is reminiscent of the cardiac phenotype found in heterotaxy, a malformation complex previously associated with functional cilia abnormalities and aberrant Hedgehog (Hh) signaling. Recent experimental data provide new insights into the relationship between Hh signaling and AVCD in other genetic conditions, including Noonan and Down syndromes.

\subsection{Atrioventricular canal defect}

AVCD, also known as endocardial cushion defect or atrioventricular septal defect, is a common congenital heart defect (CHD), affecting 3.5/10.000 live births, and accounting for 7.4\% of all CHDs. ${ }^{3}$

AVCD is characterized by a spectrum of anomalies of the atrioventricular valves, and atrial and ventricular septa. In the complete form, a single common atrioventricular valve occurs with an atrial septal defect (ostium primum), and a confluent posterior ventricular septal defect. In the partial form, two separate right and left atrioventricular valves are found with a cleft of the mitral valve, an atrial septal defect (ostium primum), and no ventricular septal communication. ${ }^{4}$

From an embryological point of view, AVCD, with absent or incomplete fusion of ventral (antero-superior) and dorsal (postero-inferior) atrioventricular cushions, was traditionally considered caused by a primary intracardiac mechanism consisting in the maldevelopment of endocardial cushions in relation to defects of extracellular matrix. ${ }^{5-7}$ Some recent studies, however, have shown that perturbation of extracardiac tissue, known as DMP, represents a major determinant of AVCD..$^{8-10}$ This population of extracardiac mesenchymal cells was reported in 1880 by Wilhelm His as spina vestibuli. 
These cells arise from the posterior segment of the SHF in the splanchnic mesoderm, grow towards the atrial surface of the primitive AVCD, in particular, towards the inferior dorsal endocardial cushion, to close the primary atrial foramen and form the AV junction. ${ }^{11,12}$

AVCD is a CHD frequently associated with extracardiac anomalies (75\%), ${ }^{3}$ familiar as the distinctive CHD in Down syndrome. ${ }^{13}$ Indeed, in large series of individuals with AVCD, extracardiac anomalies were present in about $75 \%$ of cases, ${ }^{3,14}$ of whom, 45\% had Down syndrome. Many patients with AVCD occur in syndromes of known etiologies (chromosome, gene). The second specific association is heterotaxy, occurring in 15\% of patients with AVCD. Heterotaxy is also known as Ivemark syndrome or atrial isomerism or situs ambiguous with splenic anomalies. ${ }^{4}$ The $15 \%$ of the cases of AVCD are affected by other different genetic syndromes. Non-syndromic conditions are observed in the remaining 25\% of AVCD individuals. ${ }^{14}$ The morphology and combination of CHDs in several syndromes with AVCD as reported in the 1990s in personal observations is similar to what seen in heterotaxy. ${ }^{15-19}$

1

\subsection{Ciliary function and the Hedgehog signaling pathway}

The cilium is a multifunctional organelle which projects from the cell surface of many different cells. Cilia are conserved in a wide variety of eukaryotic species throughout evolution. Studies in the last 15 years have shown that dysfunctional cilia can lead to several human genetic diseases with overlapping phenotypes, the so called "ciliopathies". ${ }^{20,21}$ The affected tissues are as diverse as the different cell types that carry cilia. The ciliary membranes harbor receptors for crucial signaling cascades, including Hh signaling. ${ }^{22,23}$ Disruption of cilium function in a single tissue may result in a tissue-restricted phenotype, while disruption of cilium function at early embryonic stages, and perturbation of proper Hh signaling, is generally associated to more severe disorders, and may not be compatible with embryonic development. 
Molecular advances have shown that several disease genes implicated in syndromes with AVCD encode proteins that participate in the ciliary function, and that dysfunction of the nodal cilium results in left-right axis defects in vertebrates. ${ }^{24,25}$ Ciliary dysfunction and abnormal localization and/or function of proteins participating in Hh signaling have been recognized in syndromes with AVCD, which is not surprising since the relevant role of Hh signaling in coordinating multiple aspects of leftright lateralization and cardiovascular growth. In addition, Sonic Hedgehog knock-out mice show CHDs in the setting of heterotaxy and left pulmonary isomerism. ${ }^{26-28}$

Genetic defects of ciliary function are known as ciliopathies, and include short rib-polydactyly, Joubert, Oral-Facial.-Digital, Bardet-Biedl, and Meckel syndromes. Hh signaling is an essential developmental pathway coordinated at the primary cilium. ${ }^{29}$ In vertebrates, three Hh signaling molecules, Sonic hedgehog (SHH), Indian hedgehog ( $\mathrm{IHH})$, and Desert hedgehog (DHH). Their effects are mediated by three different transcription factors, glioma-associated oncogenes 1 to 3 (GLI1-3). The binding of Hh molecules to their receptors, Patched 1 and 2 (PTCH1-2), results in the internalization and lysosomal degradation of the PTCH1/SHH complexes and in the release of the inhibition on smoothened (SMOH). SMOH translocates to cilia and functions as the activator of the pathway promoting transcriptional activation of the GLI proteins. ${ }^{30-33}$

Experimental studies performed in mice have shown that cilia are required for both left/right body axis determination and SHF Hh signaling. ${ }^{2}$ Dnah11 mutants, affecting ciliary motility, do not disrupt SHF Hh signaling, but cause AVCD, concurrently with heterotaxy. Differently, Mks1 mutants create dysfunction in the structure of primary cilium, disrupt SHF Hh signaling, and cause AVCD without heterotaxy. In summary, normal structure of primary cilia is required for SHF Hh signaling: both cilia structure and motility can generate distinct cardiac phenotypes.

It has been found that perturbations of the different components of SHH pathway are associated with different developmental errors in patients manifesting partially overlapping features. ${ }^{19,34}$ In the 
following paragraphs, we will review the role of Hh pathway and ciliary dysfunction in the development of AVCD in some genetic disorders.

\subsection{Heterotaxy}

Heterotaxy is characterized by the combination of the abnormal arrangement of the abdominal and thoracic organs, usually with complex CHDs, including AVCD, common atrium, anomalous systemic and pulmonary venous drainage, persistent left superior vena cava with unroofed coronary sinus, and conotruncal defects. ${ }^{4,35,36}$ Heterotaxy includes patients with situs inversus and situs ambigous with "asplenia” (right isomerism phenotype) and "polysplenia” (left isomerism phenotype). Patients with asplenia or polysplenia may be associated with cardiac and extracardiac malformations different from each other. ${ }^{37-43}$ Patients with the "asplenia phenotype" (right isomerism of lungs and atrial appendages) display right pulmonary and right atrial appendage isomerism and more severe cardiac defects, ${ }^{37,39}$ such as total anomalous pulmonary venous drainage, ${ }^{38,40,44}$ complete AVCD, ${ }^{38,40,45}$ and pulmonary stenosis or atresia. ${ }^{38,40,46}$ In contrast, the "polysplenia phenotype" is characterized by left isomerism of lungs and atrial appendages, in general with less severe $\mathrm{CHD},{ }^{38,40}$ such as partial AVCD, interruption of the inferior vena cava, ${ }^{37,38,40,41,44}$ and systemic outflow tract obstruction, ${ }^{47-50}$ which are rare in asplenia. ${ }^{51}$

\subsection{Ciliopathies with postaxial polydactyly}

This group of disorders includes several genetically heterogeneous conditions sharing AVCD and postaxial polydactyly. AVCD, particularly in association with common atrium, has been reported in several syndromes with postaxial polydactyly, including Ellis-van Creveld syndrome and other "short rib-polydactlyly” (SRP) disorders, oral-facial-digital syndromes, Bardet-Biedl syndrome, and SmithLemli-Opitz syndrome. ${ }^{15,34}$ The original clinical observation of cardiac anatomical similarities between patients with polydactyly syndromes and heterotaxy and polysplenia ${ }^{15}$ has been corroborated by 
experimental studies in transgenic mice. The suggested involvement of the SHH pathway in syndromes with postaxial polydactyly and heterotaxy has been confirmed by the detection of ciliary dysfunction in several disorders with polydactyly. Ciliary dysfunction through abnormal processing of the Hh proteins has been documented in Ellis-van Creveld and other short-rib polydactyly, Smith-Lemli-Opitz, and oral-facial-digital type IV syndromes, ${ }^{19,52,53}$ while ciliary function directly is involved in Bardet-Biedl, oral-facial-digital I and VI syndromes. ${ }^{54-57}$

\subsubsection{Ellis-van Creveld syndromes}

The Ellis-van Creveld syndrome is a chondroectodermal dysplasia, characterized by skeletal and craniofacial abnormalities associated with polydacyly, dysplastic teeth and nails. ${ }^{58}$ Approximately two thirds of the affected individuals also have CHD, more commonly AVCD associated with common atrium and/or systemic and pulmonary venous abnormalities. ${ }^{14,15,17,18,59-61}$ AVCD is rarely associated with common atrium in the non-syndromic patients, but relatively common in Ellis-van Creveld syndrome ${ }^{15}$ and in heterotaxy. ${ }^{38}$

Ellis-van Creveld syndrome is due to mutations in EVC and EVC2 genes, and both genes are required for normal transcriptional activation of IHH signalling. ${ }^{52,58}$ Specifically, EVC and EVC2 act as positive modulators of IHH signaling, located at the proximal end of the primary cilium and expressing normally in the growth plates and chondrocyte cilia. ${ }^{62}$ In the growth plates of long bones, IHH is secreted by the prehypertrophic chondrocytes, generating a gradient of signal that coordinates chondrocyte differentiation, chondrocyte proliferation and perichondrial development. ${ }^{63}$ The bulk of the Ellis-van Creveld complex localizes to the proximal end of cilia, just above the transition zone, and physically interacts with the main activator of the pathway, $\mathrm{SMOH}$, retaining this protein to that section of the cilium. ${ }^{64}$ Experiments in Evc knock-out mice have shown that loss of Evc and Evc2 function affect Ihh signaling, and expression levels of Ihh downstream targets (Ptch1, Gli1, and Pthrp). As a result, the cilia-mediated response to Hh ligands is diminished. ${ }^{65}$ Recently, a proportion of patients with 
clinical diagnosis of Ellis-van Creveld syndrome has been linked to mutations in WDR35, which encodes a retrograde intraflagellar transport (IFT) protein that is required for the recruitment of the EVC-EVC2-SMOH complex to the cilium. ${ }^{66}$ Experiments in WDR35 ${ }^{-/ 2}$ fibroblasts have shown that the mutations associated with Ellis-van Creveld syndrome lead to Hh signaling defects similar to what observed in cells with EVC or EVC2 loss of function. ${ }^{67}$ In addition, mouse models for the WDR35 gene mutations result in congenital abnormalities usually associated with defects in the Hh signaling pathway. ${ }^{67}$ More recently, biallelic DYNC2LI1 variants have been identified as a novel molecular event underlying Ellis-van Creveld syndrome in small number of families. ${ }^{68,69}$ DYNC2LI1 codes for a component of the intraflaggelar transport-related dynein-2 complex, a machinery mediating retrograde traffic along the cilium, and whose function is required for cilium assembly and function, including signal transduction, and is functionally related to WDR35.

\subsubsection{Oral-Facial-Digital syndromes}

The oral-facial-digital (OFD) syndromes include a group of conditions (13 clinical subtypes), in association with malformations of the face, oral cavity, and digits (polysyndatyly).$^{70} \mathrm{CHD}$ is not common in this group, but AVCD has been detected in patients with OFD syndrome type $\mathrm{II}^{71}$ and type $\mathrm{VI},{ }^{72}$ and common atrium in OFD syndrome type $\mathrm{I}^{73}$

OFD I can be differentiate from other subtypes by X-linked dominant inheritance and mutations of OFD1 gene, encoding for a centrosomal protein involved in ciliary function. ${ }^{74}$ Interestingly, it has been demonstrated that knockout male mouse embryos lacking this gene (Ofd1) have failure of leftright axis specification with abnormal cardiac tube retaining a midline position or reversal of the heart loop. ${ }^{55}$ Ultrastructural analysis has shown lack of cilia in the embryonic node, supporting a specific role for Ofd1 protein in cilium assembly through basal body dysfunction. OFD type II has been recently linked to the planar cell polarity ciliogenesis WDPCP gene, ${ }^{75}$ and truncating TCTN3 mutations, a gene implicated in transduction of SHH signalling, have been found in patients with atypical forms of OFD 
type IV. ${ }^{53}$

\subsubsection{Joubert syndrome}

Joubert syndrome is a group of genetically heterogeneous conditions classified among ciliopathies,

characterized by multiorgan involvement (retinal, renal, hepatic and skeletal) and the pathognomonic neuroradiological “molar tooth sign”. Joubert syndromes can be associated also with CHDs, including left ventricular obstructions, alone or associated with AVCD. ${ }^{15,76}$

\subsubsection{Smith-Lemli-Opitz syndrome}

Smith-Lemli-Opitz syndrome (SLOS) is an autosomal recessive syndrome characterized by developmental delay, growth retardation, microcephaly, distinct facial anomalies, cleft palate, hypospadias, postaxial polydactyly, and CHD. ${ }^{77}$ SLOS is due to an inborn error of cholesterol metabolism with deficiency of the 7-dehydrocholesterol-7 reductase (DHCR7) activity resulting in reduced plasma and tissue cholesterol levels and elevated 7-dehydrocholesterol concentrations due to inactivating mutations in the DHCR7 gene. ${ }^{78}$

CHD occurs in half of the patients with RSH/SLOS. ${ }^{79}$ Septal defects and AVCD are the most common CHDs in SLOS, and AVCD is often associated with anomalous pulmonary venous return, the latter is also a cardiac manifestation of heterotaxy with asplenia. ${ }^{79}$

Cholesterol plays a critical role in formation of the normally active hedgehog proteins. ${ }^{80}$

Abnormal processing of Hedgehog proteins secondary to abnormal cholesterol levels seems to have a role in the development of SLO syndrome malformations. ${ }^{19,80}$

\subsection{Ciliopathies without polydactyly}

\subsubsection{VACTERL Association}

VACTERL is a non-random association of congenital anomalies, including vertebral defects (V), anal atresia (A), esophageal atresia (TE), radial and renal dysplasia (R) and limb anomalies (L). ${ }^{81}$ This 
spectrum was broadened to include diverse CHDs which are noted in 50-80\% of patients, and include septaland and conotruncal defects. ${ }^{82}$ In addition, laterality defects have been observed, and include dextrocardia, heterotaxy, AVCD, and transposition of the great arteries. ${ }^{14,83}$

The causal mechanism underlying VACTERL association has not been established. Clinical observations and molecular studies focused on Shh signaling in mice strongly suggest that the VACTERL phenotype observed in humans could be caused by a defective SHH signaling. ${ }^{84}$ In fact, Gli mutant mice display a spectrum of defects resembling the human VACTERL association. As anticipated, GLI genes encode transcription factors mediating SHH signal transduction. In addition, VACTERL with hydrocephalus (VACTERL-H) has been associated to a hypomorphic mutation of the intraflagellar transport protein 172 (Ift172), in mice. ${ }^{85}$ Ift172 is required for ciliogenesis and Hh signaling. Thus, the IFT defect could impair the localization of Hh signaling components to the distal ciliary axoneme. CHDs in avc1 mutant mice include AVCD with common atrium. ${ }^{85}$ Some studies have implicated the FOX transcription factor gene cluster in VACTERL association. ${ }^{86}$ Haploinsufficiency of Foxf1 gene in mice can be associated with a variable phenotype that includes lung immaturity and hypoplasia, fusion of right lung lobes, narrowing of esophagus and trachea, esophageal atresia and tracheo-esophageal fistula. ${ }^{87}$ The above mechanism does involve the Hh signaling pathway, since it has been demonstrated that exogenous Shh activates transcription of Foxf1 in the developing lung. ${ }^{87}$

\subsubsection{Alveolar Capillary Dysplasia with Misaligned Pulmonary Veins}

In humans, FOXF1 gene mutations cause alveolar capillary dysplasia with misaligned pulmonary veins. ${ }^{88}$ Alveolar capillary dysplasia, usually associated with misalignment of the pulmonary vessels, is a congenital pulmonary vascular abnormality characterized histologically by a lack of formation and ingrowth of alveolar capillaries leading to a failing air-blood barrier. In about $10 \%$ of cases, alveolar capillary dysplasia is associated with CHD, in particular partial or complete AVCD and various degrees of left heart obstruction. ${ }^{89}$ AVCD in these cases may consist in a small left ventricle with or 
without aortic coarctation.

The FOXF1 gene is activated by Shh signaling and, on a specific genetic background, its haploinsufficiency results in lung and foregut malformations similar to those observed in Shh and Gli mutants. ${ }^{87}$

\subsubsection{Noonan syndrome and related disorders (RASopathies)}

The term RASopathies, also known as the Noonan Syndrome-spectrum disorder (i.e., LEOPARD syndrome or “Noonan syndrome-Multiple Lentigines”, cardio-facio-cutaneous syndrome, Costello syndrome, Mazzanti syndrome and others), are characterized by distinctive facial features, CHD, growth retardation, hematological, ectodermal and skeletal defects, and variable neuropsychologic impairment. ${ }^{90}$ CHD occurs in about $65-85 \%$ of cases, depending on the mutated genes. AVCD, usually a partial form, may occur in Noonan syndrome and in LEOPARD syndrome/Noonan syndromeMultiple Lentigines, ${ }^{91-93}$ and may be associated with systemic obstructions including subaortic stenosis or aortic coarctation. ${ }^{91,93}$ Structural abnormalities causing congenital subaortic stenosis include accessory fibrous tissue and/or anomalous insertion of mitral valve and anomalous papillary muscle of left ventricle. ${ }^{94}$

Noonan syndrome and related disorders are caused by mutations in genes encoding proteins with a role in the RAS/MAP kinase (MAPK), signaling pathway. ${ }^{90,95}$ PTPN11 gene mutations, which underlie Noonan and LEOPARD/Noonan syndrome -Multiple Lentigines syndromes, have been detected in patients with AVCD associated with RASopathies. ${ }^{93}$ It has been established that germline mildly activating mutations in PTPN11 cause Noonan syndrome, whereas more activating mutations in the same gene transmitted as somatic events cause childhood myeloproliferative disease and leukemias. $^{96}$

Strikingly, heterozygous inactivating mutations of PTPN11 gene have been associated in patients with metachondromatosis, a rare autosomal dominant tumor syndrome characterized by the 
predisposition of forming multiple exostoses and enchondromas, joint destruction and bony

deformities. ${ }^{97,98}$ Of note, chondroid neoplasms result from decreased ERK pathway activation, increased Indian hedgehog (IHH) and parathyroid hormone-related protein (PTHRP), and excessive

proliferation. Normal SHP2/PTPN11 function seems to act as IHH suppressor, and experiments in mice have documented decreased IHH levels in Noonan syndrome caused by germline activating mutations in PTPN11 gene..$^{99}$

\subsubsection{Down syndrome}

Down syndrome, which is caused in most cases by complete trisomy of 21, is characterized by developmental delay, facial anomalies, and gastrointestinal malformations. CHDs occur in about 40$50 \%$ of these patients, typically complete AVCD ${ }^{100}$ Children with Down syndrome show a "simple type" of AVCD, usually complete, rarely associated with other CHDs, with the notable exception of tetralogy of Fallot. ${ }^{101}$ In fact, associated CHDs, in particular left-sided obstructions, are significantly more rare in patients with Down syndrome and AVCD in comparison of patients with AVCD and normal chromosomes. ${ }^{13,49,100,102}$

The molecular relationship between AVCD and Down syndrome is still unclear. A number of genes located in the CHD critical region on chromosome 21 have been causally related to AVCD, including DSCAM, COL6A1, COL6A2, and DSCR1, ${ }^{103-104}$ so as variants in genes mapping on other chromosomes including CRELD1, FBLN2, FRZB, and GATA5. ${ }^{105}$ Experimental studies, using mouse models of Down syndrome, consisting in crossing loss-of-function alleles of Creld1 or Hey2 genes onto the trisomic background, showed a significant increased frequency of CHD, suggesting an interaction between modifiers and trisomic genes. ${ }^{106}$

Some recent observations in mouse models have pointed to a role of the Shh signaling pathway also in Down syndrome. Cerebral, skin, liver and intestine mice trisomic cells have shown a defective 
mitogenic Shh activity with cell proliferation impairment due to a higher expression of Ptch1, a receptor normally repressing the Shh pathway. ${ }^{107}$ This suggests that PTCH-dependent inhibition of SHH signaling may underlie proliferation impairment in trisomic peripheral tissues leading to defective neuronal production in the Down syndrome brain. ${ }^{108}$ In addition, subcutaneous administration of the Shh pathway agonist SAG to trisomic Ts65Dn mice at birth resulted in an increased proliferation of granule cell precusors in the cerebellum. ${ }^{109}$

\subsubsection{Non-syndromic AVCD}

Non-syndromic AVCD can be a sporadic or display familial clustering. In this latter case, familial recurrence follows an autosomal dominant pattern of inheritance. Little is known about molecular basis of non-syndromic AVCD. The first chromosomal locus for isolated ACVD was assigned to chromosome 1p31-p21, and a second locus was mapped within the 3p25 critical region, with CRELD1 as a putative candidate gene. ${ }^{110}$ Based on the association between AVCD and 8p deletion, GATA4 was also considered as a possible relevant gene, but thus far a pathogenic mutation was found only in a single patient.

The gene most frequently associated with AVCD is CRELD1, and heterozygous mutations occur in $6 \%$ of non-syndromic partial AVCDs. ${ }^{110}$ In addition, some CRELD1 gene mutations have been implicated in AVCD present in Down syndrome patients. ${ }^{111}$ Gene interaction has been found also in the Ts65Dn model of Down syndrome mice, where the introduction of a null allele of Creld1 in theDs65Dn mouse was observed to increase the penetrance of CHDs. It was also found that overexpression of Jam2 gene was a necessary potentiator of the disomic genetic modifier Creld1. ${ }^{112}$ Incomplete penetrance has been documented in families with AVCD, arguing that deleterious CRELD1 mutations function as risk factors for AVCD, while can occur as benign variants in the general population. One CRELD1 mutation, c.985C>T (p.Arg329Cys has been reported as a recurrent 
variant. ${ }^{111}$ A pathogenic link with ciliary dysfunction has been suspected also for CRELD1 gene. ${ }^{113}$ Based on the model analysed by Burnicka-Turek et al. ${ }^{2}$ CRELD1 is not required for left/right determination, since Creld1 null mice do not manifest L/R abnormalities, ${ }^{114}$ suggesting that CRELD1 mutations contribute to the cause of AVCD through disruption of SHF Hh signaling rather than cilia motility. In the same study, it was suggested that hypomorphic mutations of the genes contributing to primary cilia structure and signaling could contribute also to the development of non-syndromic AVCDs.

\subsection{Pathogenetic mechanism of AVCD: the role of Sonic Hedgehog}

Nonsyndromic AVCD is a CHD with genetic heterogeneity. It involves a progenitor and secondary fields, and is homologous to AVCD in related species who share corresponding structure due to descent with modification from a common ancestor. ${ }^{115,116}$ Tissue of extracardiac origin, from the posterior segment of the SHF (the so-called dorsal mesocardial protrusion (DMP) is recognized as a fundamental component of atrial and atrioventricular septation of the heart. ${ }^{8-10,117}$ Cells of the DMP growing towards the primary atrial septum fuse with the posteroinferior and anterosuperior atrioventricular cushions to close the primary atrial foramen and to form two separate atrioventricular valves. ${ }^{8,10-12}$

In mice, defects of Shh signaling cause developmental anomalies of the DMP resulting in AVCD. ${ }^{1,12,118}$ Abnormal expression of Shh signaling in the DMP disrupts the proliferation of this structure, preventing the fusion of the atrioventricular cushions with the inferior margin of the septum primum. ${ }^{1,12}$ Additional experimental studies have shown that Shh null mouse heart can have AVCD. ${ }^{119,120}$ Nevertheless, the primary AVCD signal transduction cascade involves Hh parsimoniously since $\mathrm{Hh}$ is involved in the induction of other developmental fields, as neural and ocular holoprosencephaly, anterior-posterior limb axis and ventral somites. 
Therefore, perturbation of the SHH pathway and its effect on the DMP, represent unifying pathogenic patterns, causing AVCD in many genetic disorders, including Down and Noonan syndromes.

\section{CONCLUSIONS}

Hh signaling coordinates multiple aspects of left-right lateralization and cardiovascular growth, and being active at venous pole of the SHF, it is essential for normal development of dorsal-mesenchymal protrusion and AVC formation and septation. Molecular studies have demonstrated that several genes responsible for syndromes with AVCD are causally involved in ciliary function and/or abnormal processing of proteins with role in Hh signaling. Perturbations of different components of the Hh pathway lead to several developmental errors presenting with partially overlapping manifestations and AVCD as a common denominator (Figure 1, Table 1).

Similarly to that occurring for conotruncal heart defects in deletion 22q11.2 syndrome and branchial arch anomalies, AVCD should be considered as the cardiac manifestation linking ciliopathy syndromes. AVCD could be part of a "developmental field”, accordingly to the concept that malformations can be due to defects in signal transduction cascades or pathways in developmental field defects. ${ }^{115,116}$ The single morphogenetic unit may be altereted by Mendelian mutations, aneuploidies, and environmental causes.

\section{REFERENCES}

1. Goddeeris MM, Rho S, Petiet A, et al. Intracardiac septation requires hedgehog-dependent cellular contributions from outside the heart. Development. 2008;135:1887-1895.

2. Burnicka-Turek O, Steimle JD, Huang W, et al. Cilia gene mutations cause atrioventricular septal defects by multiple mechanisms. Hum Molec Genet. 2016:25:3011-3028. 
3. Ferencz C, Loffredo CA, Correa-Villasenor A, Wilson PD. Genetic and environmental risk factors of major cardiovascular malformations. The Baltimore-Washington Infant Study 19811989. Armonk, New York: Futura Publishing Company Inc.; 1997.

4. Van Praagh S, Antoniadis S, Otero-Coto E, Leidenfrost RD, Van Praagh R. Common atrioventricular canal with and without conotruncal malformations: An anatomic study of 251 postmortem cases. In: Nora JJ, Takao A (eds): “Congenital heart disease: Causes and Processes.” Mount Kisko, NY: Futura Publishing, 1984, pp 599-639.

5. Clark EB. Mechanism in the pathogenesis of congenital heart defects. In: Pierpont ME, Moller J. The Genetics of Cardiovascular Disease. Boston, MA: Martinus- Nijoff: 1986. 3-11 p.

6. Clark EB. Pathogenetic mechanism of congenital cardiovascular malformations revisited. Semin Perinatal. 1996;29:465-472.

7. Pierpont ME, Markwald RR, Lin AE. Genetic aspects of atrioventricular septal defects. Am $J$ Med Genet. 2000;97:289-296.

8. Lamers WH, Moorman AF. Cardiac septation: a late contribution of the embryonic primary myocardium to heart morphogenesis. Circ Res. 2002;91:93-103.

9. Blom NA, Ottenkamp J, Wenink AG, Gittenberger-de Groot AC. Deficiency of the vestibular spine in atrioventricular septal defects in human fetuses with down syndrome. Am J Cardiol. 2003;91:180-184.

10. Gittenberger-de Groot AC, Calkoen EE, Poelmann RE, Bartelings MM, Jongbloed MR. Morphogenesis and molecular considerations on congenital cardiac septal defects. Ann Med. 2014;46:640-652.

11. Snarr BS, Wirrig EE, Phelps AL, Trusk TC, Wessels A. A spatiotemporal evaluation of the contribution of the dorsal mesenchymal protrusion to cardiac development. Dev Dyn. 2007;236:1287-1294. 
12. Briggs LE, Kakarla J, Wessels A.The pathogenesis of atrial and atrioventricular septal defects with special emphasis on the role of the dorsal mesenchymal protrusion. Differentiation. 2012;84:117-130.

13. Marino B, Vairo U, Corno A, et al. Atrioventricular canal in Down sindrome. Prevalence of associated cardiac malformations compared with patients without Down syndrome. Am J Dis Child. 1990;144:1120-1122.

14. Digilio MC, Marino B, Toscano A, Giannotti A, Dallapiccola B. Atrioventricular canal defect without Down syndrome: a heterogeneous malformation. Am J Med Genet. 1999;85:140-146.

15. Digilio MC, Marino B, Ammirati A, Borzaga U, Giannotti A, Dallapiccola B. Cardiac malformations in patients with oral-facial-skeletal syndromes: clinical similarities with Heterotaxy. Am J Med Genet. 1999;84:350-356.

16. Marino B, Reale A, Giannotti A, Digilio MC, Dallapiccola B. Nonrandom association of atrioventricular canal and del (8p) syndrome. Am J Med Genet. 1992;42:424-427.

17. Digilio MC, Marino B, Giannotti A, Dallapiccola B. Single atrium, atrioventricular canal/postaxial hexodactyly indicating Ellis-van Creveld syndrome. Hum Genet. 1995;96:251253.

18. Digilio MC, Marino B, Giannotti A, Dallapiccola B. The atrioventricular canal defect is the congenital heart disease connecting short rib-polydactyly and oral-facial-digital syndromes. Am J Med Genet. 1997;68:110-112.

19. Digilio MC, Versacci P, Lepri F, Baban A, Dallapiccola B, Marino B. Atrioventricular canal defect and associated genetic disorders: New insights into polydactyly syndromes. Cardiogenetics. 2011;e7.

20. Tobin JL, Beales PL. The nonmotile ciliopathies. Genet Med. 2009;11:386-402. 
21. Waters AM, Beales PL. Ciliopathies: an expanding disease spectrum. Pediatr Nephrol. 2011;26:1039-1056.

22. Huangfu D, Liu A, Rakeman AS, Murcia NS, Niswander L, Anderson KV. Hedgehog signalling in the mouse requires intraflagellar transport proteins. Nature. 2003;426:83-87.

23. Anderson KV. Cilia and Hedgehog signaling in the mouse embryo. Harvey Lect. 2006;102:103-115.

24. Supp DM, Witte DP, Potter SS, Brueckner M. Mutation in an axonemal dynein affects left-right asimmetry in inversus viscerum mice. Nature. 1997;389:963-966.

25. Okada Y, Nonaka S, Tanaka Y, Saijoh Y, Hamada H, Hirokawa N. Abnormal nodal flow precedes situs inversus in iv and inv mice. Mol Cell. 1999;4:459-468.

26. Chiang C, Litingtung Y, Lee E, et al. Cyclopia and defective axial patterning in mice lacking Sonic hedgehog gene function. Nature. 1996 ;383:407-413.

27. Meyers EN, Martin GR. 1999. Differences in left-right axis pathways in mouse and chick: functions of FGF8 and Shh. Science. 285:403-406.

28. Tsukui T, Capdevila J, Tamura K, et al. Multiple left-right asymmetry defects in Shh(-/-) mutant mice unveil a convergence of the shh and retinoic acid pathways in the control of Lefty1. Proc Natl Acad Sci USA. 1999;96:11376-11381.

29. Ingham PW, Nakano Y, Seger C. Mechanisms and functions of Hedgehog signaling across the metazoa. Nat Rev Genet. 2011;12:393-406.

30. Corbit KC, Aanstad P, Singla V, Norman AR, Stainier DY, Reiter JF. Vertebrate smoothened functions at the primay cilium. Nature. 2005;437:1018-1021.

31. Haycraft CJ, Banizs B, Aydin-Son Y, Zhang Q, Michaud EJ, Yoder BK. Gli2 and Gli3 localize to cilia and require the intraflagellar transport protein polaris for processing and function. PloS Genet. 2005;1:e53. 
32. Haycraft CJ, Zhang Q, Song B, et al. Intraflagellar transport is essential for endochondral bone formation. Development. 2007;134:307-316.

33. Hooper JE, Scott MP. Communicating with Hedgehogs. Nat Rev Mol Cell Boil. 2005;6:306317.

34. Digilio MC, Marino B, Giannotti A, Dallapiccola B, Opitz JM. Specific congenital heart defects in RSH/Smith-Lemli-Opitz syndrome: postulated involvement of the sonic hedgehog pathway in syndromes with postaxial polydactyly or Heterotaxy. Birth Defects Res A Clin Mol Teratol. 2003;67:149-153.

35. Webber SA, Taylor GP, Colwell K, Sandor GGS, Patterson MWH. Extracardiac malformations in asplenia syndrome. Cardiol Young. 1992;2:136-140.

36. Phoon CK, Neill CA. Asplenia syndrome: Insight into embryology through an analysis of cardiac and extracardiac anomalies. Am J Cardiol. 1994;73:581-587.

37. Rose V, Izukawa T, Moes CA. Syndromes of asplenia and polysplenia. A review of cardiac and non-cardiac malformations in 60 cases with special references to diagnosis and prognosis. $\mathrm{Br}$ Heart J. 1975;37:840-852.

38. Peoples WM, Moller JH, Edwards JE. Polysplenia: a review of 146 cases. Pediatr Cardiol. 1983;4:129-38.

39. Hashmi A, Abu-Sulaiman R, McCrindle BW, Smallhorn JF, Williams WG, Freedom RM. Management and outcomes of right atrial isomerism: a 26-year experience. J Am Coll Cardiol. 1998;31:1120-1126.

40. Gilljam T, McCrindle BW, Smallhorn JF, Williams WG, Freedom RM. Outcomes of left atrial isomerism over a 28-year period at a single institution. J Am Coll Cardiol. 2000;36:908-916.

41. Ticho BS, Goldstein AM, Van Praagh R. Extracardiac anomalies in the heterotaxy syndromes with focus on anomalies of midline-associated structures. Am J Cardiol. 2000;85:729-734. 
42. Van Praagh S. Cardiac malpositions and the heterotaxy syndromes. In, Nadas’ Pediatric Cardiology. Second Edition. Elsevier. 2006. 675-695 p.

43. Lin AE, Krikov S, Riehle-Colarusso T, et al. Laterality defects in the national birth defects prevention study (1998-2007): Birth prevalence and descriptive epidemiology. Am J Med Genet. 2014;164A:2581-2591.

44. Rubino M, Van Praagh S, Kadoba K, Pessotto R, Van Praagh R. Systemic and pulmonary venous connections in visceral heterotaxy with asplenia. Diagnostic and surgical considerations based on seventy-two autopsied cases. J Thorac Cardiovasc Surg. 1995;110:641-650.

45. Francalanci P, Marino B, Boldrini R, Abella R, Iorio F, Bosman C. Morphology of the atrioventricular valve in asplenia syndrome: A peculiar type of atrioventricular canal defect. Cardiovasc Pathology. 1996;5:145-151.

46. Vitiello R, Moller JH, Marino B, Vairo U, Edwards JE, Titus JL. Pulmonary circulation in pulmonary atresia associated with the asplenia cardiac syndrome. J Am Coll Cardiol. 1992;20:363-365.

47. Vairo U, Marino B, Parretti di Iulio D, et al. Right atrial isomerism with pulmonary atresia, the angiocardiographic characteristics and pulmonary circulatory patterns. G It Cardiol. 1991;21:669-674.

48. Marino B. Atrioventricular septal defect - anatomic characteristics in patients with and without Down’s sindrome. Cardiol Young. 1992;2:308-310.

49. Carotti A, Marino B, Oppido G, Marcelletti C. Biventricular repair in patients with left isomerism. J Thorac Cardiovasc Surg. 1995;110:1151-1152.

50. Van Praagh, Geva T, Friedberg DZ, et al. Aortic outflow obstruction in visceral heterotaxy: a study based on twenty postmortem cases. Am Heart J. 1997;133:558-569. 
51. Marino B, Pasquini L. Systemic and venous connection in asplenia syndrome. $J$ Thorac Cardiovasc Surg. 1996;111:1109.

52. Ruiz-Perez VL, Blair HJ, Rodriguez-Andres ME, et al. Evc is a positive mediator of Ihhregulated bone growth that localises at the base of chondrocyte cilia. Development. 2007;134:2903-2912.

53. Thomas S, Legendre M, Saunier S, et al. TCTN3 Mutations Cause Mohr-Majewski Syndrome. Am J Hum Genet. 2012;91:372-378.

54. Ansley SJ, Badano JL, Blacque OE, et al. Basal body dysfunction is a likely cause of pleiotropic Bardet-Biedl syndrome. Nature. 2003;425:628-633.

55. Ferrante MI, Zullo A, Barra A, et al. Oral-facial-digital type I protein is required for primary cilia formation and left-right axis specification. Nat Genet. 2006;38:112-117.

56. Digilio MC, Dallapiccola B, Marino B. Atrioventricular canal defect in Bardet-Biedl syndrome: clinical evidence supporting the link between atrioventricular canal defect and polydactyly syndromes with ciliary dysfunction. Genet Med. 2006;8:536-538.

57. Valente EM, Logan CV, Mougou-Zerelli S, et al. Mutations in TMEM216 perturb ciliogenesis and cause Joubert, Meckel and related syndromes. Nat Genet. 2010;42:619-625.

58. Ruiz-Perez VL, Goodship JA. Ellis-van Creveld syndrome and Weyers acrodental dysostosis are caused by cilia-mediated diminished response to Hedgehog ligands. Am J Med Genet. 2009;151C:341-351.

59. Digilio MC, B Marino, A Giannotti, B Dallapiccola. Atrioventricular canal defect and postaxial polydactyly indicating phenotypic overlap of Ellis-van Creveld and Kaufman-McKusick syndromes. Pediatr Cardiol. 1997;18:74-75.

60. Digilio MC, Giannotti A, Torrente I, et al. Ellis-van Creveld syndrome with hydrometrocolpos is not linked to chromosome arm 4p or 20p. Am J Med Genet. 2004;126A:319-323. 
61. Digilio MC, Dallapiccola B, Marino B. Atrioventricular canal defect as a sign of laterality defect in Ellis-van Creveld and polydactyly syndromes with ciliary and hedgehog signaling dysfunction. Pediatr Cardiol. 2012:33:874-875.

62. Caparros-Martin JA, Valencis M, Reytor E. The ciliary Evc/Evc2 complex interacts with Smo and controls Hedgehog pathway activity in chonmdrocytes by regulating Sufu/Gli3 dissociation and Gli3 trafficking in primary cilia. Hum Mol Genet. 2013;22:124-139.

63. Kronenberg HM. Developmental regulation of the growth plate. Nature. 2003;423:332-336.

64. Dorn KV, Hughes CE, Rohatgi R. A Smoothened-Evc2 complex transduces the Hedgehog signal at primary cilia. Dev Cell. 2012;23:823-835.

65. Blair HJ, Tompson S, Liu Y-N, et al. Evc2 is a positive modulator of Hedgehog signalling that interacts with Evc at the cilia membrane and is also found in the nucleus. BMC Biology. 2011;9:14.

66. Caparrós-Martín JA, De Luca A, Cartault F, et al. WDR35 is required for recruitment of the Evc-Evc2 complex to the cilium. Hum Molec Genet. 2015;24:4126-4137.

67. Mill P, Lockhart PJ, Fitzpatrick E, et al. Human and mouse mutations in WDR35 cause short-rib polydactyly syndromes due to abnormal ciliogenesis. Am J Hum Genet. 2011;88:508-515.

68. Taylor SP, Dantas TJ, Duran I, et al. Mutations in DYNC2LI2 disrupt cilia function and cause short rib polydactyly syndrome. Nat Commun. 2015;6:7092.

69. Niceta M, Margiotti K, Digilio MC, et al. Biallelic mutations in DYNC2LI1 are a rare cause of Ellis-van Creveld syndrome. Clin Genet. 2017 (online)

70. Gurrieri F, Franco B, Toriello H, Neri G. Oral-facial-digital syndromes: review and diagnostic guidelines. Am J Med Genet. 2007;143A:3314-3323.

71. Digilio MC, Marino B, Giannotti A, Dallapiccola B. Orocardiodigital syndrome: an oral-facialdigital type II-variant associated with atrioventricular canal. J Med Genet. 1996;33:416-418. 
72. Gustavson KH, Kreuger A, Petersson PO. Syndrome characterized by lingual malformation, polydactyly, tachypnea, and psychomotor retardation (Mohr syndrome). Clin Genet. 1971;2:261-266.

73. Su WR, Wang PH, Lian JD, Lin MC. Oral-facial-digital syndrome with vaginal atresia, hydronephrosis and congenital cardiac defect. J Pediatr Orthop. 2008;17:179-182.

74. Singla V, Romaguera-Ros M, Garcia-Verdugo JM, Reiter JF. Ofd1, a human disease gene, regulates the length and distal structure of centrioles. Dev Cell. 2010;18:410-424.

75. Saari J, Lovell MA, Yu H-C, Bellus GA. Compound heterozygosity for a frame shift mutation and a likely pathogenic sequence variant in the planar cell polarity-Ciliogenesis gene WDPCP in a girl with polysyndactyly, coarctation of the aorta, and tongue hamartomas. Am J Med Genet. 2015;167A:421-427.

76. Karp N, Grosse-Wortmann L, Bowdin S. Severe aortic stenosis, bicuspid aortic valve and atrial septal defect in a child with Joubert Syndrome and Related Disorders (JSRD) - A case report and review of congenital heart defects reported in the human ciliopathies. Eur J Med Genet. 2012;55:605-610.

77. Kelley RI, Hennekam RC. The Smith-Lemli-Opitz syndrome. J Med Genet. 2000;37:321-335.

78. Moebius FF, Fitzky BU, Lee JN, Paik YK, Glossmann H. Molecular cloning and expression of the human delta7-sterol reductase. Proc Natl Acad Sci USA. 1998;95:1899-1902.

79. Lin AE, Ardinger HH, Ardinger RH, Cunniff C, Kelley RI. Cardiovascular malformations in Smith-Lemli-Opitz syndrome. Am J Med Genet. 1997;68:270-278.

80. Chamoun Z, Mann RK, Nellen D, et al. Skinny hedgehog, an acyltransferase required for palmitolation and activity of the hedgehog signal. Science. 2001;293:1080-2084. 
81. Källén K, Mastroiacovo P, Castilla EE, Robert E, Källén B. VATER non-random association of congenital malformations: Study based on data from four malformation registers. Am J Med Genet. 2001;101:26-32.

82. Botto LD, Khoury MJ, Mastroiacovo P, et al. The spectrum of congenital anomalies of the VATER association: An international study. Am J Med Genet. 1997;71:8-15.

83. Weaver DD, Mapstone CL, Yu P-I. The VATER association. Analysis of 46 patients. Am J Dis Child. 1986;140:225-229.

84. Kim JH, Kim PCW, Hui C-C. The VACTERL association: lessons from the Sonic Hedgehog pathway. Clin Genet. 2001;59:306-315.

85. Friedland-Little JM, Hoffmann AD, Ocbina PJ, et al. A novel murine allele of Intraflagellar Transport Protein 172 causes a syndrome including VACTERL-like features with hydrocephalus. Hum Mol Genet. 2011;20:3725-3737.

86. Shaw-Smith C. Genetic factors in esophageal atresia, tracheoesophageal fistula and the role of VACTERL association: Roles for FOXF1 and the 16q24.1 FOX transcription factor gene cluster, and review of the literature. Eur J Med Genet. 2010;53:6-13.

87. Mahlapuu M, Enerbäck S, Carlsson P. Haploinsufficiency of the forkhead gene Foxf1, a target for sonic hedgehog signaling, causes lung and foregut malformations. Development. $2001 ; 128: 2397-2406$.

88. Sen P, Yang Y, Navarro C, et al. Novel FOXF1 Mutations in sporadic and familial cases of alveolar capillary dysplasia with misaligned pulmonary veins imply a role for its DNA binding domain. Hum Mutat. 2013;34:801-811.

89. Laux D, Malan V, Bajolle F, Boudjemline Y, Amiel J, Bonnet D. FOX gene cluster defects in alveolar capillary dysplasia associated with congenital heart disease. Cardiol Young. 2013;23:697-704. 
90. Tartaglia M, Zampino G, Gelb BD. Noonan syndrome: Clinical aspects and molecular pathogenesis. Mol Syndromol. 2010;1:2-26.

91. Marino B, Digilio MC, Toscano A, Giannotti A, Dallapiccola B. Congenital heart diseases in children with Noonan syndrome: An expanded cardiac spectrum with high prevalence of atrioventricular canal. J Pediatr. 1999;135:703-706.

92. Sarkozy A, Conti E, Seripa D, et al. Correlation between PTPN11 gene mutations and congenital heart defects in Noonan and LEOPARD syndromes. J Med Genet. 2003;40:704708.

93. Digilio MC, Lepri FR, Dentici ML, et al. Atrioventricular canal defect in patients with RASopathies. Eur J Hum Genet. 2013;21:200-204.

94. Marino B, Gagliardi MG, Digilio MC, et al. Noonan syndrome: structural abnormalities of the mitral valve causing subaortic obstruction. Eur J Pediatr. 1995;154: 949-952.

95. Aoki Y, Niihori T, Inoue S, Matsubara Y. Recent advances in RASopathies. J Hum Genet. 2016;61:33-39.

96. Tartaglia M, Martinelli S, Cazzaniga G, et al. Genetic evidence for lineage-related and differentiation stage-related contribution of somatic PTPN11 mutations to leukemogenesis in childhood acute leucemia. Blood. 2004;104:307-313.

97. Sobreira NL, Cirulli ET, Avramopoulos D, et al. Whole-genome sequencing of a single proband together with linkage analysis identifies a Mendelian disease gene. PLoS Genet. 2010;6:e1000991.

98. Bowen ME, Boyden ED, Holm IA, et al. Loss-of-function mutations in PTPN11 cause metachondromatosis, but not Ollier disease or Maffucci syndrome. PLoS Genet. 2011;7:e1002050. 
99. Yang W, Wang J, Moore DC, et al. Ptpn11 deletion in a novel progenitor causes metachondromatosis by inducing hedgehog signalling. Nature. 2013;499:491-496.

100. Marino B. Congenital heart disease in patients with Down's syndrome: anatomic and genetic aspects. Biomed \& Pharmacother. 1993;47:197-200.

101. Nguyen HH, Jay PY. A single misstep in cardiac development explains the cooccurrence of tetralogy of fallot and complete atrioventricular septal defect in Down syndrome. J Pediatr. 2014;165:194-196.

102. De Biase L, Di Ciommo V, Ballerini L, Bevilacqua M, Marcelletti C, Marino B. Prevalence of left-sided obstructive lesions in patients with atrioventricular canal without Down’s syndrome. J Thorac Cardiovasc Surg. 1986;91:467-469.

103. Jongewaard IN, Lauer RM, Behrendt DA, Patil S, Klewer SE. Beta 1 integrin activation mediates adhesive differences between trisomy 21 on non-trisomic fibroblasts on type VI collagen. Am J Med Genet. 2002;109:298-305.

104. Arron JR, Winslow MM, Polleri A, et al. NFAT dysregulation by increased dosage of DSCR1 and DYRK1A on chromosome 21. Nature. 2006;441:595-600.

105. Ackerman C, Locke AE, Feingold E, et al. An excess of deleterious variants in VEGF-A pathway genes in Down-syndrome-associated atrioventricular septal defects. Am J Hum Genet. 2012;91:646-659.

106. Li H, Cherry S, Klinedinst D, et al. Genetic modifiers predisposing to congenital heart disease in the sensitized Down syndrome population. Circ Cardiovasc Genet. 2012;5:301-308. 107. Fuchs C, Ciani E, Guidi S, Trazzi S, Bartesaghi R. Early-occurring proliferation defects in peripheral tissues of the Ts65Dn mouse model of Down syndrome are associated with patched1 over expression. Lab Invest. 2012;92:1648-1660. 
108. Trazzi S, Mitrugno VM, Valli E, et al. APP-dependent up-regulation of Ptch1 underlies proliferation impairment of neural precursors in Down syndrome. Hum Molec Genet. 2011;20:1560-1573.

109. Das I, Park J-M, Shin JH, et al. Hedgehog agonist theraphy correct structural and cognitive deficits in a Down syndrome mouse model. Sci Trasl Med. 2013;5:201ra120.

110. Guo Y, Shen J, Yuan L, Li F, Wang J, Sun K. Novel CRELD1 gene mutations in patients with atrioventricular septal defect. World J Pediatr. 2010;6:348-352.

111. Maslen CL, Babcock D, Robinson SW, Bean LJ, Dooley KJ, Willour VL, Sherman SL. CRELD1 mutations contribute to the occurrence of cardiac atrioventricular septal defects in Down syndrome. Am J Med Genet. 2006;140A:2501-2505.

112. Li H, Edie S, Klinedinst D, et al. Penetrance of congenital heart defects in a mouse model of Down syndrome depends on a trisomic potentiator of a disomic modifier. Genetics. 2016;203:763-770.

113. Blacque OE, Perens EA, Boroevich KA, et al. Functional genomics of the cilium, a sensory organelle. Curr Biol. 2005;15:935-941.

114. Redig JK, Fouad GT, Babcock D, et al. Allelic interaction between CRELD1 and VEGFA in the pathogenesis of cardiac atrioventricular septal defects. AIMS Genet .2014;1:119.

115. Opitz JM, Neri G. Historical perspective on developmental concepts and terminology. Am J Med Genet. 2013;161A:2711-2725.

116. Opitz JM. Phenotypes, pleiotropy, and phylogeny. Am J Med Genet. 2017C;175:329340. 
117. Tasaka H, Krug EL, Markwald RR. Origin of the pulmonary venous orifice in the mouse and its relation to the morphogenesis of the sinus venosus, extracardiac mesenchyme (spina vestibuli), and atrium. Anat Rec. 1996;246:107-113.

118. Hoffmann AD, Yang XH, Burnicka-Turek O, et al. Foxf genes integrate tbx5 and hedgehog pathways in the second heart field for cardiac sepation. PloS Genet. 2014;10:e1004604.

119. Washington Smoaka I, Byrdb NA, Abu-Issab R, et al. Sonic hedgehog is required for cardiac outflow tract and neural crest cell development. Developmental Biology. 2005;283:357_ 372.

120. Hildreth V, Webb S, Chaudhry B, et al. Left cardiac isomerism in the Sonic hedgehog null mouse. J Anat. 2009;214:894-904. 


\section{Legenda figure}

FIGURE 1. Different mechanisms altering Hedgeghog signaling pathway in syndromes associated with AVCD

RSH/Smith-Lemli Opitz syndrome

Ellis-van Creveld syndrome Oral-Facial-Digital I syndrome Oral Facial-Digital IV syndrome Oral-Facial-Digital VI syndrome Joubert syndromes

Kartagener syndrome

VACTERL Association

Alveolar capillary dysplasia

Noonan syndrome

Down syndrome
Low cholesterol

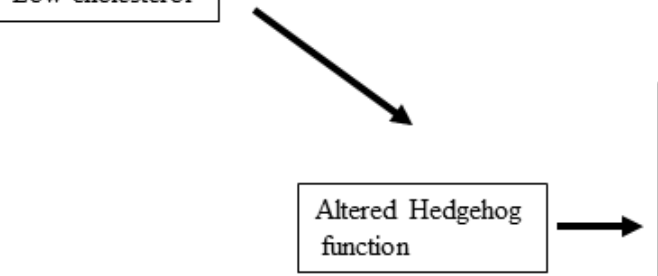

Gene variant
Heterotaxia

AVCD with common atrium

AVCD with APVR

AVCD with left-sided obstructions Situs inversus

Postaxial-polydactyly 
TABLE 1. Review of genes, mutation effects in Hedgehog pathway, cilia involvement, and cardiac defects in ciliopathies with AVCD

\begin{tabular}{|c|c|c|c|c|c|c|c|c|}
\hline $\int^{\text {Disease }}$ & Gene & $\begin{array}{l}\text { Mutation } \\
\text { effect on } \\
\text { Hedgehog } \\
\text { pathway }\end{array}$ & $\begin{array}{l}\text { Cilia } \\
\text { involvement }\end{array}$ & $\begin{array}{l}\text { AVCD and } \\
\text { laterality } \\
\text { defects }\end{array}$ & $\begin{array}{l}\text { Left-sided } \\
\text { obstructions }\end{array}$ & $\begin{array}{l}\text { Pulmonary } \\
\text { venous } \\
\text { abnormalities }\end{array}$ & $\begin{array}{l}\text { Conotruncal } \\
\text { defects }\end{array}$ & $\begin{array}{l}\text { Septal } \\
\text { defects, } \\
\text { other }\end{array}$ \\
\hline $\begin{array}{l}\text { Ellis-van Creveld } \\
\text { syndrome }\end{array}$ & $\begin{array}{l}\text { EVC } \\
\text { EVC2 } \\
\text { WDR35 } \\
\text { DYNC2LI1 }\end{array}$ & $\begin{array}{l}\text { Decrease of } \\
\text { Ihh }\end{array}$ & $\begin{array}{l}\text { Proximal end of } \\
\text { the primary } \\
\text { cilium }\end{array}$ & $\begin{array}{l}\text { AVCD (partial) } \\
\text { with } \\
\text { common atrium }\end{array}$ & $\begin{array}{l}\text { HLH, Ao Co, } \\
\text { AS }\end{array}$ & & & $\begin{array}{l}\text { ASD } \\
\text { (ostium } \\
\text { secundum) }\end{array}$ \\
\hline $\begin{array}{l}\text { Oral-Facial- } \\
\text { Digital syndromes }\end{array}$ & & & & & & & & \\
\hline - OFD type I & Ofd1 & - & $\begin{array}{l}\text { Basal body of the } \\
\text { primary cilia }\end{array}$ & $\begin{array}{l}\text { Situs inversus } \\
\text { Common atrium }\end{array}$ & - & & & \\
\hline - OFD type II & WDPCP & $\begin{array}{l}\text { Involvement } \\
\text { of Hedgehog } \\
\text { pathway }\end{array}$ & $\begin{array}{l}\text { Basal body of the } \\
\text { primary cilia }\end{array}$ & $\begin{array}{l}\text { AVCD (partial) } \\
\text { with } \\
\text { common atrium } \\
\end{array}$ & $\begin{array}{l}\text { HLH, Ao Co, } \\
\text { AS }\end{array}$ & & & \\
\hline - OFD type VI & TMEM216 & - & $\begin{array}{l}\text { Basal body of the } \\
\text { primary cilia }\end{array}$ & AVCD (partial) & Ao Co, AS & & & \\
\hline Joubert syndromes & KIF7 & \begin{tabular}{|l|} 
Increased in \\
activity of Shh \\
pathway, \\
through \\
regulation of \\
Gli
\end{tabular} & $\begin{array}{l}\text { Microtubule } \\
\text { dynamics } \\
\text { Basal body of the } \\
\text { primary cilia }\end{array}$ & AVCD (partial) & AS, BAV & & & \\
\hline $\begin{array}{l}\text { Smith Lemli- } \\
\text { Opitz syndrome }\end{array}$ & DHCR7 & $\begin{array}{l}\text { Abnormal } \\
\text { processing of } \\
\text { the Hedgehog } \\
\text { proteins } \\
\text { secondary to } \\
\text { low } \\
\text { cholesterol } \\
\end{array}$ & - & $\begin{array}{l}\text { AVCD } \\
\text { (complete) with } \\
\text { APVR }\end{array}$ & & APVR & & $\begin{array}{l}\text { VSD, } \\
\text { ASD } \\
\text { (ostium } \\
\text { secundum) }\end{array}$ \\
\hline
\end{tabular}




\begin{tabular}{|c|c|c|c|c|c|c|c|c|}
\hline $\begin{array}{l}\text { Kartagener } \\
\text { syndrome }\end{array}$ & Dyneins & \begin{tabular}{|l|} 
Not required \\
for SHF \\
Hedgehog \\
signaling.
\end{tabular} & $\begin{array}{l}\text { Dynein arms, } \\
\text { linking } \\
\text { microtubules } \\
\text { Cilia motility }\end{array}$ & Situs inversus & - & & & \\
\hline $\begin{array}{l}\text { VACTERL } \\
\text { Association } \\
\text { As }\end{array}$ & $\begin{array}{l}\text { GLI3, } \\
\text { FOXF1, } \\
\text { IFT172 }\end{array}$ & $\begin{array}{l}\text { Defective } \\
\text { Sonic and } \\
\text { Indian } \\
\text { Hedgehog } \\
\text { signaling }\end{array}$ & $\begin{array}{l}\text { Distal ciliary } \\
\text { axoneme }\end{array}$ & $\begin{array}{l}\text { AVCD (partial) } \\
\text { Dextrocardia } \\
\text { Heterotaxy }\end{array}$ & & APVR & $\begin{array}{l}\text { TOF, } \\
\text { DORV }\end{array}$ & $\begin{array}{l}\text { VSD } \\
\text { (subaortic), } \\
\text { ASD } \\
\text { (ostium } \\
\text { secundum) }\end{array}$ \\
\hline $\begin{array}{l}\text { Alveolar capillary } \\
\text { dysplasia }\end{array}$ & FOXF1 & $\begin{array}{l}\text { Activated by } \\
\text { Sonic } \\
\text { Hedgehog } \\
\text { signalling }\end{array}$ & - & $\begin{array}{l}\text { AVCD (partial) } \\
\text { with left-sided } \\
\text { obstructions }\end{array}$ & - & & & \\
\hline $\begin{array}{l}\text { Noonan / } \\
\text { RASopathies }\end{array}$ & PTPN11 & $\begin{array}{l}\text { Decreased } \\
\text { Indian } \\
\text { Hedgehog } \\
\text { levels }\end{array}$ & - & $\begin{array}{l}\text { AVCD (partial) } \\
\text { with Ao Co }\end{array}$ & Ao Co & & & $\begin{array}{l}\text { PVS, } \\
\text { ASD } \\
\text { (ostium } \\
\text { secondum) }\end{array}$ \\
\hline Down syndrome & \begin{tabular}{|l} 
Trisomy \\
21
\end{tabular} & \begin{tabular}{|l|} 
Defective \\
mitogenic \\
Sonic \\
Hedgehog \\
activity \\
\end{tabular} & - & $\begin{array}{l}\text { AVCD } \\
\text { (complete) } \\
\text { with/without } \\
\text { TOF }\end{array}$ & & & TOF & $\begin{array}{l}\text { VSD } \\
\text { (inlet), } \\
\text { ASD } \\
\text { (ostium } \\
\text { secundum) } \\
\end{array}$ \\
\hline $\begin{array}{l}\text { Non-syndromic } \\
\text { AVCD }\end{array}$ & CRELD1 & $\begin{array}{l}\text { Disruption of } \\
\text { Hedgehog } \\
\text { signaling } \\
\end{array}$ & $\begin{array}{l}\text { Primary cilium } \\
\text { structure }\end{array}$ & $\begin{array}{l}\text { AVCD (partial, } \\
\text { complete) }\end{array}$ & - & & & \\
\hline
\end{tabular}

Abbreviations : Ao Co, aortic coarctation; APVR, anomalous pulmonary venous return; AS, aortic stenosis; ASD, atrial septal defect; AVCD,

atrioventricular canal defect ; BAV, bicuspid aortic valve; DORV, double outlet right ventricle; HLH, hypoplastic left heart; Ihh : Indian Hedgehog; OFD, Oral-Facial-Digital, PVS, pulmonary valve stenosis; TOF, tetralogy of Fallot; VSD, ventricular septal defect. 